\title{
Osseointegration: a review of the fundamentals for assuring cementless skeletal fixation
}

This article was published in the following Dove Press journal:

Orthopedic Research and Reviews

25 April 2014

Number of times this article has been viewed

Brad M Isaacson ${ }^{1,2}$

Sujee Jeyapalina ${ }^{3,4}$

'Henry M Jackson Foundation for the Advancement of Military Medicine,

${ }^{2}$ The Center for Rehabilitation

Sciences Research, Department of

Physical Medicine and Rehabilitation,

Uniformed Services University of

Health Sciences, Bethesda, MD,

USA; ${ }^{3}$ Department of Orthopedics,

${ }^{4}$ Orthopedic Research Laboratory,

University of Utah, Salt Lake City, UT, USA
Correspondence: Brad M Isaacson

Tel + I 6107727252

Email brad.isaacson.ctr@usuhs.edu

\begin{abstract}
Direct skeletal fixation, termed osseointegration, has expanded in the last century and includes use in total joint replacements, the edentulous mandible and maxilla, and percutaneous osseointegrated prosthetics. Although it is well known that titanium and bone have the ability to form a durable bone-implant interface, new applications have emerged in the field of orthopedics, which requires a more thorough assessment of the literature. This review aims to introduce the basic biological principles for attaining osseointegration and discusses the major factors for assuring successful cementless fixation.
\end{abstract}

Keywords: osseointegration, bone, skeletal attachment, total joint replacements, dental implants, percutaneous

\section{Introduction to osseointegration}

Surgical implantation of metals and ceramics has been used to restore function for individuals with diseased and compromised tissue for the past 200 years. ${ }^{1}$ However, the success of direct skeletal attachment with metal substrates remained limited until Per-Ingvar Brånemark discovered the integration potential between titanium and bone. ${ }^{2}$ Brånemark and his coworkers coined the term "osseointegration" (OI) to describe the ability of titanium to form a mechanical and functional interconnection with osseous tissue without the formation of interpositioned connective tissue. ${ }^{3}$ The definition of OI has continued to evolve over the years given the advancement in imaging and microscopic tools available for assessing the bone-implant interface (Table 1). Current descriptions of $\mathrm{OI}$ include the need of the periprosthetic bone to resist shear and tensile forces ${ }^{4}$ and to be within $50 \mu \mathrm{m}$ distance from the implant surface to host bone to prevent fibrous tissue attachment. ${ }^{5}$

Since the initial scientific discovery by Brånemark and his colleagues, fixation of metallic and nonmetallic implants to bone has increased exponentially in the fields of dentistry and orthopedics. OI has been used as a means to fix dental implants, bone-anchored hearing aids, spinal fusion implants, and endo-exo prostheses. Clinical follow up of oral, craniofacial, and cementless total joint replacements (TJR) has reported long-term clinical success rates with high implant survivorship. ${ }^{6-17}$ The principle factors for achieving direct skeletal fixation have been reported to include: the implant surface properties; quality of the host bone; surgical site preparation; loading conditions; implant design; and preventing initial and chronic infections. These factors are reported within this review, with the goal of improving the current understanding of OI and spurring future innovation in this field. 
Table I Advantages and disadvantages of various testing modalities

\begin{tabular}{|c|c|c|c|}
\hline Testing modality & Advantage & Disadvantage & References \\
\hline Light microscopy & Inexpensive technique & $\begin{array}{l}\text { Does not provide sufficient detail at the interfacial } \\
\text { zone because the resolution capacity is only } 0.1 \mathrm{~mm}\end{array}$ & 143 \\
\hline $\begin{array}{l}\text { Microcomputed tomography } \\
(\mu-C T)\end{array}$ & $\begin{array}{l}\text { Provides three-dimensional images } \\
\text { of the bone-implant construct }\end{array}$ & $\begin{array}{l}\text { Image artifacts occur due to the opaque nature } \\
\text { of the titanium-based implant }\end{array}$ & $\mid 44-148$ \\
\hline Resonance frequency & $\begin{array}{l}\text { A nondestructive technique shown to } \\
\text { correlate with mechanical removal forces } \\
\text { and bone ingrowth or ongrowth }\end{array}$ & $\begin{array}{l}\text { Implant stability quotient values do not provide } \\
\text { sufficient detail of host bone-implant integration }\end{array}$ & $149-154$ \\
\hline Backscatter electron imaging & High resolution & Expensive technique & 155,156 \\
\hline
\end{tabular}

\section{Bone biology and osseointegration The implant surface}

Various metals, ceramics, and biostable polymers have been used to achieve OI. The major metal types have included: cobalt chromium, ${ }^{18-20}$ tantalum, ${ }^{21}$ stainless steel, ${ }^{19,20,22}$ zirconium, ${ }^{23,24}$ and commercial pure titanium and its alloys. 19,20,22 However, titanium has been widely advocated as the most biocompatible material for promoting OI, due to its excellent mechanical properties, ${ }^{25}$ resistance to corrosion, ${ }^{25,26}$ and its ability to develop an oxide layer on the surface (comprised of a dioxide chemical structure, $\mathrm{TiO}_{2}$ ). ${ }^{27,28}$ Most interestingly, this oxide layer thickness has been noted to be dynamic, ranging between 1,000-2,000 $\AA$ at 7 years postoperative follow up - much higher than the initial measurement of 60-100 $\AA$ reported at the time of implantation. ${ }^{4,21}$ The ability for bone to both mechanically and chemically bind to the surface of titanium has been known to facilitate durable OI and longterm implant survivorship (Figure 1).

Roughness, porosity, topography, and surface energy all contribute to the host response to a titanium implant placed in apposition with cortical and/or cancellous bone. ${ }^{29,30}$ While a complete review of each of these topics is not within the scope of this paper, some brief generalizations regarding the material surface are worth noting. It is well observed that the implant surface morphology directly influences osteoblast and osteoclast attachment and metabolism. ${ }^{31}$ Skeletal fixation is most effective when using porous implants $(50-400 \mu \mathrm{m})^{32}$ with roughened surfaces, where ingrowth and interdigitation of the newly formed bone into the porous structure stabilizes the interface (Figure 2). As stated by Boyan et al, implant surfaces should have a 4-7 $\mu \mathrm{m}$ layer of roughness to ensure proper osteoblast cuboid morphology, ${ }^{33}$ an essential characteristic for assuring OI. Osteoblasts seated on roughened surfaces have demonstrated increased proliferation, and previous in vivo animal models have reported that the textured surfaces required higher removal torques compared with smooth controls. ${ }^{29}$

The implant surface is a key factor in direct skeletal fixation, with implant survivorship dependent upon the specific device design and anatomical location for OI. Given the differences in mechanical loading conditions, vascular integrity, host bone quality (bone mineral density [BMD] and bone mineral content $[\mathrm{BMC}]$ ), and bone type (cortical vs cancellous), surface properties may in future be tailor-made for each unique application (Figure 3). While in general, smooth implants do not have a microtexture conducive for osteoconduction, Balshe et al noted, when comparing 2,182 smooth-surface dental implants and 2,425 roughened implants postoperatively, that survival rates were $94.0 \%$ and
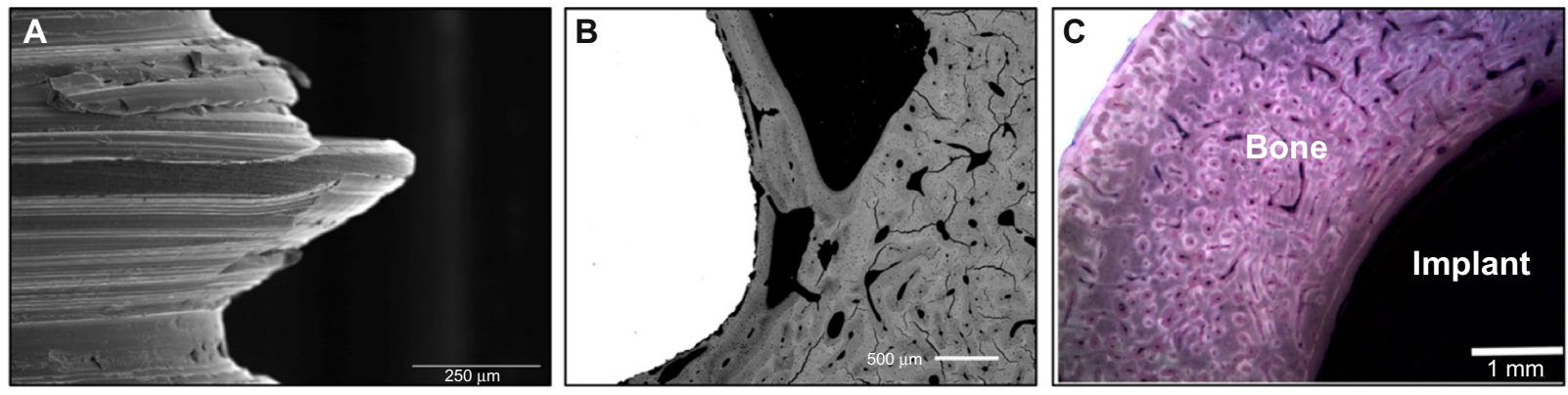

Figure I (A) Representative scanning electron microscope image demonstrating high resolution along the screw threads of an implant used for osseointegration. (B) BSE micrograph of bone-implant cross section, clearly depicting the bone on-growth (gray) onto the implant (white) within $50 \mu \mathrm{m}$. (C) Bone-implant cross-section stained with Sanderson's Rapid BoneStain ${ }^{\mathrm{TM}}$ and counter stained with acid fuchsin, showing bone and implant interconnection.

Note: Sanderson's Rapid Bone Stain ${ }^{\mathrm{TM}}$ (Surgipath Medical Industries, Richmond, IL, USA).

Abbreviation: BSE, back-scattering electron. 


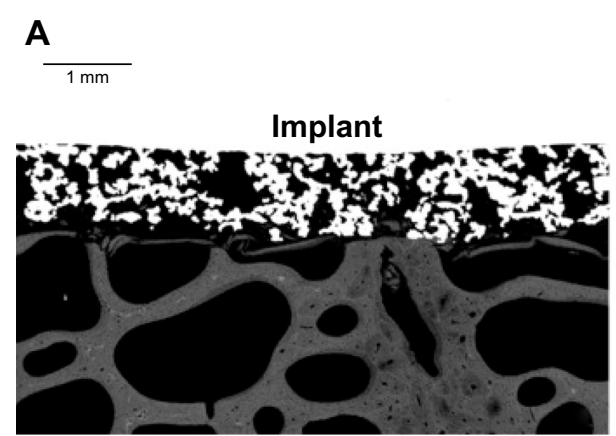

At surgery
B

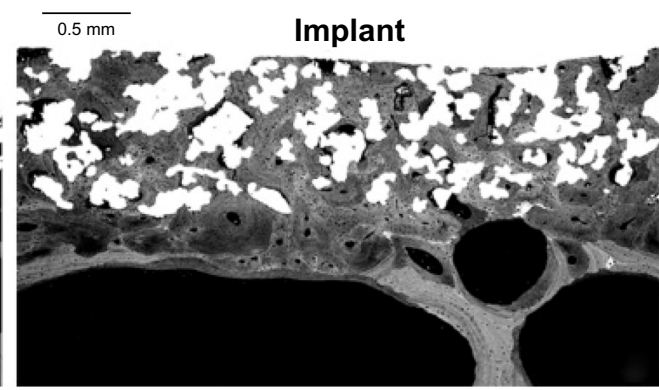

6 months postsurgery

Figure 2 A representative set of BSE micrographs showing the ingrowth and interdigitation of new bone tissue into the porous, coated region at 6 months postsurgery (B) compared with time 0 (at surgery), when the implant was placed in close apposition with the host bone (A). The image shows porous coating (white), bone (gray), and marrow cellular components (black).

Abbreviation: BSE, back-scattering electron.

$94.5 \%$, respectively. ${ }^{34}$ However, Balshe et al reported that the implant length and anatomic location were significant predictors for smooth implant failure ${ }^{34}$ and that surface properties may be overridden when implants were placed at a sufficient depth within the osseous tissue. Pak et $\mathrm{al}^{35}$ supported the potential for smooth implant attachment and noted, in their histomorphometric studies of dental implants with three separate surface treatments (commercially pure titanium, tricalcium phosphate, and anodic corrosion), that there were no differences in bone-implant contact or localized bone volume density at 3 and 6 weeks, respectively, thereby signifying the importance of proper implant "fit and fill."

\section{Quality of the host bone}

Biological fixation between a titanium implant and host bone depends upon the quality and architecture of the supporting bone used in the OI procedure. ${ }^{36}$ The human skeleton is com-

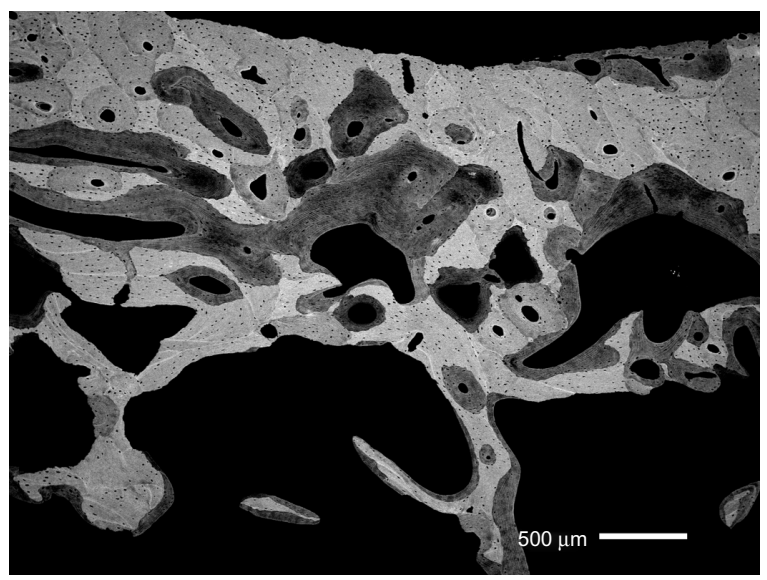

Figure 3 BSE micrograph demonstrating the wide range in bone mineralization levels during remodeling.

Abbreviation: BSE, back-scattering electron. prised of approximately $80 \%$ cortical bone and $20 \%$ cancellous bone; however, the ratio between these bone types varies greatly between anatomical locations. For instance, the cortical to cancellous bone ratio of the vertebra is $25: 75$, compared with 50:50 in the femoral head and 95:5 in the radial diaphysis. ${ }^{37}$ Given that cortical bone is typically less metabolically active than trabecular bone, ${ }^{37}$ the placement of an orthopedic implant is critical for long-term success. Also, bone formation at the periprosthetic interface has shown to be a slow but a dynamic and tightly coupled process ${ }^{38}$ coordinated between cells, ${ }^{39}$ hormones, ${ }^{40}$ and enzymes. ${ }^{38}$ Modeling and remodeling of bone tissue around an OI implant results from complex chemical interactions and mechanical stimuli.

It has been largely accepted that bone adapts to mechanical loads in accordance with Wolff's law. ${ }^{41}$ The functional adaption of bone, most studied in the proximal femur, demonstrates the unique ability of bone to alter its trabecular orientation as a result of loading conditions. ${ }^{42}$ Bone biologist, Harold Frost also described the transformation of bone as a strain-driven event. ${ }^{43}$ Frost hypothesized that a "minimal effective strain" was required to maintain bone architecture ${ }^{43}$ and that physiologic bone strains rarely exceeded $3 \%$ in vivo. ${ }^{44}$ In the absence of the minimum effective strain, bone volume will be reduced (as was the case with early astronauts who went into space). Moreover, loss of crestal bone may also result from highly localized stresses that induce microfractures. Thus, in order to maintain a healthy host bone volume and to preserve bone tissue, dental and orthopedic implants should permit adequate mechanical stimulation to the surrounding skeletal tissue.

A complete review of bone biology and the mechanical effects on bone formation has been reported in the literature previously. ${ }^{45,46}$ However, it should be noted that both BMC and BMD significantly impact the durability of OI by altering cell proliferation and protein synthesis. ${ }^{47}$ Minor increases in 
bone mineralization exponentially increase the modulus of elasticity of bone ${ }^{48,49}$ and subsequently, the durability of the bone-implant construct. However, there is a known inverse relationship between bone stiffness and fracture toughness, so minor decreases in BMC may allow the host bone to absorb higher energy prior to deformation. ${ }^{49}$ This balance in BMC may affect the longevity of OI implant survivorship, as highly mineralized bones may fracture due to their inability to absorb the kinetic energy ${ }^{49}$ - which may occur from an abrupt fall, to a patient with an OI implant.

In the case of OI within long bones, cortical bone porosity ranges between 5\%-10\% in skeletally mature individuals, while the porosity of cancellous bone varies between $50 \%-95 \%{ }^{39}$ The increased pore space of cancellous bone results in an approximate three- to eightfold reduced bone density compared with cortical bone ${ }^{44}$ and explains the 30 -fold reduction in strength and stiffness between the two bone types. ${ }^{44}$ Aside from the biomechanical advantage of cortical bone, Charnley also noted that cancellous bone does not have a periosteum along the surface of the trabeculae, ${ }^{50}$ thus contributing to one of the known metabolic differences between cortical and cancellous bone remodeling.,51,52 Moreover, cancellous bone heals in an appositional manner, with very little callus formation $(<1 \%)$, which significantly differs from the healing patterns/cascades of fractured cortical bone; this would affect bone remodeling if accidental trauma occurred to the site where an osseointegrated implant was placed.

\section{Surgical site preparation/implant stability}

While proper instrumentation and operative techniques help to minimize disturbance to the localized vascular network during OI procedures, uncontrolled thermal or mechanical factors (reaming, rasping, or drilling) used to ensure proper implant "fit and fill" or fixation may damage the host bone's ability to remodel. ${ }^{53,54}$ Insertion of an orthopedic implant into the host bone results in a localized region of necrotic tissue. ${ }^{55}$ While it has been generally agreed upon that this amount of necrotic bone should be reduced during the initial implantation, Albrektsson et al have speculated that a minor region of dead bone may act as an early implant stabilizer during the preliminary phase of bone remodeling ${ }^{21}$ and may even be beneficial for anchoring osseointegrated implants in situ. In order to prevent premature implant failure, primary implant stability must occur immediately ${ }^{56}$ to eliminate micromotion at the bone-implant site ${ }^{57}$ and to also prevent fibrous tissue formation. ${ }^{58}$ Gaps in excess of $50-150 \mu \mathrm{m}$ between the implant surface texture and host bone may lead to fibrous tissue without skeletal attachment. 5,59,60
To improve the likelihood for dental implant survivorship, novel techniques have been developed that use computed tomography scans from the patient's mouth, and computeraided design. ${ }^{61}$ Advanced implant planning in a virtual environment may improve the accuracy of dental implant fabrication and provide patient-specific replicas for surgery. In fact, a study performed by Valente et al, using computeraided oral surgery in a series of 25 patients resulted in a $96 \%$ implant survivorship, with mean deviations being less than $2 \mathrm{~mm}$ in any direction ${ }^{62}$ - thereby demonstrating the usefulness of this technique for positioning and for selecting an appropriate implant size.

Trauma to the host bone tissue during surgery may also accelerate local bone turnover. ${ }^{63-65}$ This has been termed the "regional acceleratory phenomenon" (RAP), which was first defined by Frost, using noxious stimuli, and then by Bloebaum et al. ${ }^{64,66,67}$ The RAP may occur for two reasons: the first being that placement of an intramedullary OI implant alters the dynamic strains to the host bone tissue. Depending on the "fit and fill," the implant may result in high concentrations of localized stress or "stress shielding;" $66,68,69$ second, the surgical procedure itself disrupts the blood supply to the endosteal wall (which results in a local tissue response to reestablish bone vascularity) - thus causing an increase in cortical bone porosity. ${ }^{70,71}$ This increased vascular network is optimal for bone remodeling but will impact overall strength. Knowledge of the RAP is vital for the success of OI implants. In dentistry, increasing the severity of the RAP has been reported to accelerate the rate of orthodontic tooth movement. $^{72}$

\section{Loading conditions}

One challenge with cementless fixation has been preventing micromotion during the early phases of healing and allowing the bone to form a strong skeletal interlock; ${ }^{21,73}$ if this is not achieved, a fibrous tissue interface (Figure 4) may form and prevent OI. ${ }^{74-77}$ As noted above, limiting the initial forces on an OI implant has been based on the principle that stress must be exerted gradually to promote firm skeletal attachment since under- or overloading may compromise the integrity of the host bone. To prevent mechanical loosening at the boneimplant construct, OI procedures for dental applications initially have required periods of restricted load-bearing, to avert overloading. ${ }^{78-87}$ However, the dental and TJR literature now indicates that immediate implant loading may not compromise the integrity of the bone-implant interface or prevent $\mathrm{OI}$ if micromotion is controlled with properly designed implants. ${ }^{73,80-82,86-90}$ However, key design elements must be 


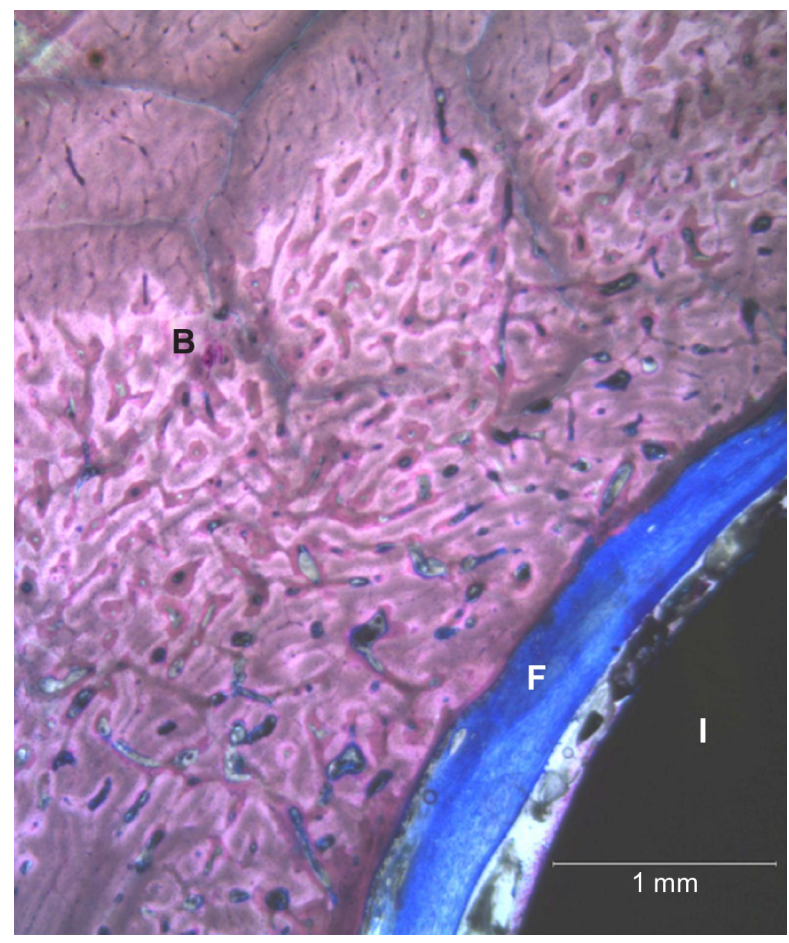

Figure $4 \mathrm{~A}$ representative bone-implant cross section that was stained with Sanderson's Rapid BoneStain ${ }^{\mathrm{TM}}$ showing the interpositioned fibrous capsule (F) between the implant (I) and the host bone tissue (B).

Note: Sanderson's Rapid Bone Stain ${ }^{\mathrm{TM}}$ (Surgipath Medical Industries, Richmond, IL, USA).

considered and include the implant neck design, screw shape, abutment design, etc during the oral implant design.

Most importantly, a delayed weight-bearing protocol deviates from the TJR paradigm, in which patients with total knee arthroplasty (TKA) or total hip arthroplasty (THA) bear loads within hours of the procedure. Literature further indicates that immediate load-bearing may occur without compromising skeletal attachment. ${ }^{91,92}$ Implant-retrieval studies have further demonstrated that early load-bearing may be permitted if careful operative protocols and implant designs with optimal porous coatings are used. ${ }^{52,76,77}$

Since the time when delayed loading for dental and orthopedic implants was first introduced, several authors have evaluated immediate loading and found high success rates that are comparable with or better than short-term protocols that require a "nondisturbed healing period." $93-97$ Degidi and Piattelli studied the clinical prognosis of 646 immediately loaded dental implants placed in 152 patients and found only six failure cases within the first 6-month period. ${ }^{98}$ Additionally, recent studies by Jeyapalina et al confirmed that when an immediate-loading protocol was used with percutaneous OI implants placed within the intramedullary canal, there were no signs of implant loosening postoperatively for up to 1 year. ${ }^{63,99-101}$ The appositional bone index, calculated at predetermined time points, demonstrated progressive bone interconnection and further validated the importance of "fit and fill" (Figure 5). These findings provide further evidence for an immediate implant loading once primary implant stability has been achieved.

\section{Implant design}

Novel designs for orthopedic implants have recently been developed using finite element analysis as a prerequisite. Hansson ${ }^{102,103}$ used computational modeling and finite element analysis of the femoral neck to reduce the peak
A

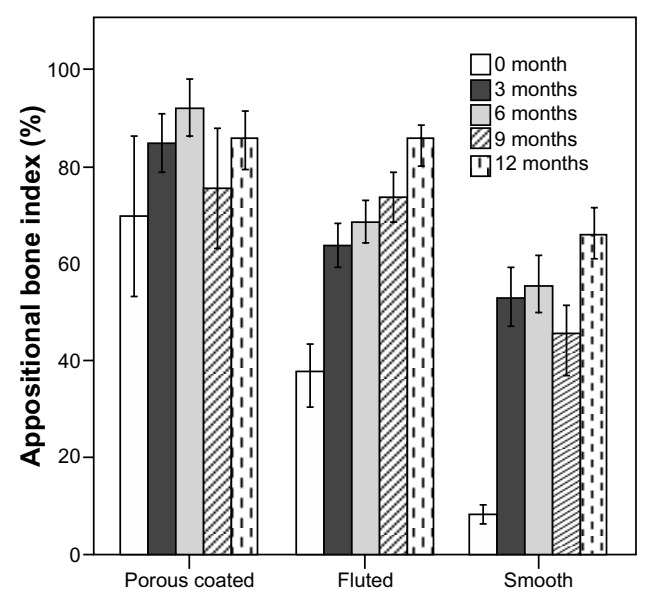

B

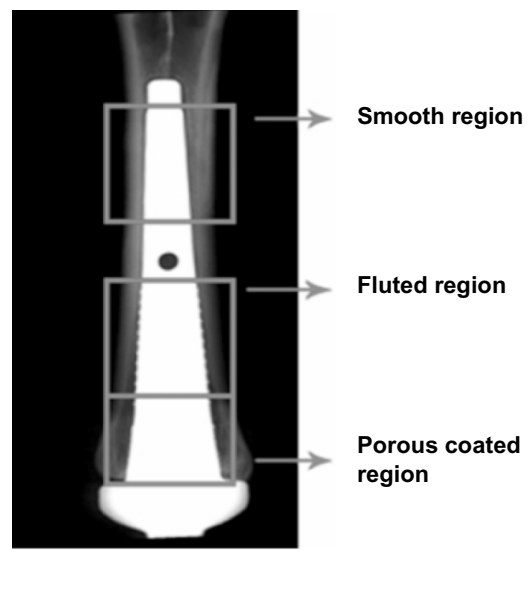

Figure $5(\mathrm{~A}) \mathrm{ABI}$ values at the time of the surgery (time 0 ) and at 3, 6, 9, and 12 months postsurgery. Data was obtained from a translational animal model, where sheep were implanted with a percutaneous OI implant in their fused right metacarpal III, IV bone. Statistically significant differences were found, between time 0 and all other time points, of fluted and smooth regions. (B) A radiographic image of the intramedullary implant, schematically showing the regions used for the $A B I$ measurements.

Notes: $A B I$ values are expressed as \%. The error bars indicate $95 \% \mathrm{Cl}(P<0.05)$.

Abbreviations: $\mathrm{ABI}$, average appositional bone index; $\mathrm{Cl}$, confidence interval; Ol, osseointegration. 
interfacial shear forces and promote axial load transfer over a greater area of peri-implant bone interfaces. Furthermore, tapered implants using this design approach and microtextured surface features, such as a porous coating, may provide more effective force dissipation over a greater bone volume - thus improving the likelihood of successful OI. ${ }^{12}$ For instance, follow up studies of the Zweymüller ${ }^{\circledR}$ hip implant system (Zimmer Holdings, Inc., Warsaw, IN, USA) have demonstrated no stem revisions and exceptionally high implant survivorship using a tapered design. ${ }^{104,105}$

\section{Preventing and treating initial and delayed infections}

Although most of the OI procedures performed in controlled sterile clinical settings are successful, implant failures have been reported and may require revision surgery. The three primary reasons for OI implant revisions are due to 1) osteolysis and related aseptic implant loosening; 2) mechanical failures due to lack of OI; and/or 3) infection. ${ }^{106,107} \mathrm{~A}$ discussion of infection is as follows.

\section{Total joint replacement}

Implant-related infection is one of the challenging obstacles to THA and TKA. It has been reported that $0.8 \%-1.9 \%$ of TKAs and $0.3 \%-1.7 \%$ of primary THAs fail due to infection, aseptic loosening, dislocation, or fracture. ${ }^{108}$ In the case of infection, the most common conventional therapy is antibiotics. However, if antibiotic therapies are unsuccessful, then the implant is often removed and reimplanted in a revision surgery. However during the revision surgery, the risk of infection is increased and has been reported to be as high as $10 \%{ }^{109}$ (this is because the dermal barrier is broken once more, allowing bacteria to reach the surgical site). In some instances the pathogen may include methicillin-resistant Staphylococcus aureus, which has high patient morbidity and mortality. One study by Mortazavi et al noted that $57 \%$ of the staphylococcal organisms cultured following deep infections after revision TKA were methicillin-resistant. ${ }^{110}$ Further compounding this problem, these bacteria may establish biofilms (sessile communities), which are difficult to eradicate with conventional antibiotic therapy. ${ }^{111,112}$ Since most chronic infections are attributed to biofilms, reoccurring deep tissue infection that cannot be managed by antibiotic therapy may require removal of all infected, devitalized, and foreign materials including the arthroplasty components. Often, the biofilm-forming bacteria may readhere to the implant if they are still present within the surrounding tissue. Therefore, in order for OI between the implant and host tissue to be successful, the revised implant must be placed in a sterile environment. To ensure sterility of the site, a two-stage reconstruction surgery is often considered, with local and systemic antibiotic treatments used in between the surgeries for cementless fixation. ${ }^{113-115}$

\section{Dental OI implants}

Bacterial colonization on dental implants may not lead to ultimate implant failure; however, prolonged exposures may generate host tissue inflammatory reactions, which slow OI progression. There are two major types of dental implant infection: peri-implant mucositis and peri-implantitis. ${ }^{116}$ While peri-implant mucositis is defined as a reversible inflammatory reaction in soft tissues surrounding an OI dental implant, peri-implantitis is considered to be an inflammatory reaction with the loss of supporting bone surrounding an implant. ${ }^{116,117}$ Pontoriero et al studied the clinical and microbiological response to the development of experimental gingivitis and experimental peri-implant mucositis and concluded that there were no significant differences found between them. ${ }^{118}$ The treatment option for peri-implant mucositis largely is based upon the management of plaque control, where surface debridement constitutes the basic element for treatment.

Peri-implantitis has an overall incidence rate of $12 \%$ $43 \% .{ }^{119}$ If the early stages of peri-implantitis persist, implantbone integration may be compromised, and subsequently, the implant will be lost. Presently, no single pathogen has been closely associated with infection of any implant system; ${ }^{120}$ however, the microbial floras of failing implants have been associated with the pathogens of periodontitis. ${ }^{120}$ Several reports cited that these implants were colonized with putative periodontal pathogens, including Peptostreptococcus micros, Fusobacterium spp., enteric gram-negative rods, and yeast. ${ }^{120-123}$ Moreover, the frequency of peri-implantitis in patients with a history of periodontitis has been reported to be four- to fivefold higher than that of individuals with no histology of periodontitis, ${ }^{124}$ thereby indicating a closer tie between both types of infections. A review of the treatment used for peri-implantitis has revealed that surgical removal of the lesion followed by cleaning of the affected implant with hydrogen peroxide, chlorhexidine, citric acid, tetracycline, lasers, etc, and a systemic antibiotic therapy are effective methods. ${ }^{120,122,125-128}$

\section{Craniofacial OI implants}

Given the reduced number of craniofacial implants performed annually, less data is available for scrutinizing bacterial colonization on these implants. However, clinical studies on the skin penetrating abutments in the temporal region show that infections are rare. As reported by Albrektsson et al, $96 \%$ of the cases of craniofacial implant had minimal 
to no skin irritation. ${ }^{129}$ When infections have occurred, they have often been mitigated by proper implant site hygiene. Topical applications of antibiotics have been used to control superficial infection, if present.

\section{Percutaneous OI implants}

Although over 200 percutaneous OI prostheses have been fit to European patients with limb loss, ${ }^{130-132}$ there have been limited published reports on infection outcomes. ${ }^{130,133-136}$ When an infection signal is present, these have been frequently treated with topical/systemic antibiotic treatment and cleaning of the device abutment. However, with deep infections, device removal becomes almost necessary. The clinical resolution of deep infections for these OI prosthetic systems resembles that of the two-stage treatment protocol used in TJR surgeries, where, the first-stage is the removal of the infected endoprosthetic components and insertion of temporary spacer with antibiotic treatment, followed by a second-stage operation to insert a new implant system. ${ }^{130}$

Although Gunterberg et al reported 75\% superficial and $37.5 \%$ deep infections in his earlier patient population of 16 individuals, ${ }^{134}$ their infection rate decreased to $37 \%$ and $18 \%$, respectively over a 3-year study period after a standardized treatment protocol was introduced in 1999. ${ }^{133}$ The suspected pathogens in these cases were reported to be $S$. aureus, coagulase-negative Staphylococcus spp., Enterococcus faecalis, and Escherichia coli. ${ }^{133}$ The reported rate was also in agreement with the UK experience of the Brånemark OI system, which had deep infection rate of approximately $18 \%$ and in some cases, required implant removal. ${ }^{137}$ In spite of the significant improvements such as surgical techniques, implant design, material selection, and implant exit site hygiene - infection still remains a concern with this implant system. Bragdon et al reported approximately one infection per 2 patient-years with the OPRA (Osseointegrated Prostheses for the Rehabilitation of Amputees) implant system (Integrum AB, Mölndal, Sweden). ${ }^{138}$

A publication by Juhnke et al from Lübeck, Germany appears promising. ${ }^{136}$ After initially having a high frequency of stomal-associated infections and revision surgery (70\%), this team reduced infections to $0 \%$ in their final design iteration. ${ }^{136}$ The researchers reported that the best infection prevention strategy is daily cleansing of the skin/implant stoma with water and a mild soap and gentle debridement of the detritus and biofilm from the interface using a shaving brush. Finally, the data from an ongoing UK clinical trial led by Dr. Blunn indicated a successful skin-to-implant integration when HA coating is used. ${ }^{131}$ A recent personal communication with this group revealed a great clinical success of this implant type in 15 transfemoral amputees. One of these amputees has already climbed mount Kilimanjaro with his percutaneous OI device.

\section{Conclusion}

Titanium and its alloys have been used in orthopedic and dental applications for the past 200 years and have significantly improved functionality for patients. While novel surface treatments continue to be developed, the basic bone healing principles still remain pertinent for $\mathrm{OI}$ and skeletal attachment. The initial attachment at the bone-implant construct is a vital prerequisite for successful OI. Durable biological fixation relies heavily on implant design and sizing in order to limit micromotion. The long-term implant survivorship varies based on the anatomical location and mechanical loading conditions.

In order to achieve durable implant-bone contact, adequate implant surface characteristics (roughness, porosity, depth of pores, etc) ${ }^{32}$ must be carefully designed to achieve skeletal fixation. Excessive micromotion between the implant and host bone will not have the structural integrity needed to withstand the dynamic shear/tensile/compressive forces occurring with load-bearing during ambulation. ${ }^{139}$ While initial implant fixation is required to prevent micromotion and fibrous encapsulation, , $29,59,74,79,82,140-142$ the long-term success of OI implants requires firm skeletal attachment, which may take up to 3 to 9 months postoperatively in human cancellous bone. ${ }^{79}$ Immediate full load-bearing in the postoperative period has several benefits, including a shorter hospital stay, lower hospitalization cost, and an earlier return to daily living.

\section{Acknowledgments}

This material is based upon work supported by the United States Department of the Army under Award Numbers W81XWH-12-2-0017 to the Henry M Jackson Foundation for the Advancement of Military Medicine, Inc. for Heterotopic Ossification, and NF90UG to the Henry M Jackson Foundation in support of the Uniformed Services University of Health Sciences' Center for Rehabilitation Science Research. Additional support is provided by the University of Utah School of Medicine, and the US Department of Defense, Peer Reviewed Medical Research Program (Grant PR054520).

\section{Disclosure}

The authors report no conflicts of interest in this work.

\section{References}

1. Williams DL, Isaacson BM. The 5 Hallmarks of Biomaterials Success: An Emphasis on Orthopaedics. Adv Biosci Biotechnol. 2014;5: 283-293.

2. Branemark PI. Vital microscopy of bone marrow in rabbit. Scand J Clin Lab Invest. 1959;11 Supp 38:S1-S82. 
3. Braånemark PI, Hansson BO, Adell R, et al. Osseointegrated implants in the treatment of the edentulous jaw. Experience from a 10-year period. Scand J Plast Reconstr Surg Suppl. 1977;16:1-132.

4. Albrektsson T, Albrektsson B. Osseointegration of bone implants. A review of an alternative mode of fixation. Acta Orthop Scand. 1987;58(5):567-577.

5. Bloebaum RD, Bachus KN, Momberger NG, Hofmann AA. Mineral apposition rates of human cancellous bone at the interface of porous coated implants. J Biomed Mater Res. 1994;28(5):537-544.

6. Brånemark PI, Gröndahl K, Worthington P. Osseointegration and Autogenous Onlay Bone Grafts: Reconstruction of the Edentulous Atrophic Maxilla. Hanover Park, IL: Quintessence Publishing Co, Inc.; 2001.

7. Brånemark PI, de Oliveira MF, editors. Craniofacial Prostheses: Anaplastology and Osseointegration. Hanover Park, IL: Quintessence Publishing Co, Inc.; 1997.

8. Brånemark P-I, Rydevik BL, Skalak R, editors. Osseointegration in Skeletal Reconstruction and Joint Replacement: Proceedings of the Second International Workshop on Osseointegration in Skeletal Reconstruction and Joint Replacement, Rancho Santa Fe, CA, October 27-29, 1994. Hanover Park, IL: Quintessence Publishing Co, Inc.; 1997.

9. Brånemark PI, Tolman DE, editors. Osseointegration in Craniofacial Reconstruction. Hanover Park, IL: Quintessence Publishing Co, Inc.; 1998.

10. Brånemark P-I, Chien S, Grondahl H-G, Robinson K, editors. The Osseointegration book: from Calvarium to Calcaneus. Hanover Park, IL: Quintessence Publishing Co, Inc.; 2005.

11. Worthington P, Brånemark PI. Advanced Osseointegration Surgery: Applications in the Maxillofacial Region. Hanover Park, IL: Quintessence Publishing Co, Inc.; 1992.

12. Ellingsen JE, Lyngstadaas SP. Bio-Implant Interface: Improving Biomaterials and Tissue Reactions. Boca Raton, FL, London: CRC Press, Inc.; 2003

13. Jokstad A, editor. Osseointegration and Dental Implants. Hoboken, NJ: Wiley-Blackwell; 2009.

14. Zarb GA, Albrektsson T, Baker G, Eckert SE, Stanford C, Tarnow DP, et al, editors. Osseointegration: On Continuing Synergies in Surgery, Prosthodontics, and Biomaterials. Hanover Park, IL: Quintessence Publishing Co, Inc.; 2008.

15. Granström G. Craniofacial osseointegration. Oral Dis. 2007;13(3): 261-269.

16. Gumieiro EH, Dib LL, Jahn RS, et al. Bone-anchored titanium implants for auricular rehabilitation: case report and review of literature. Sao Paulo Med J. 2009;127(3):160-165.

17. Goodman SB, Gómez Barrena E, Takagi M, Konttinen YT. Biocompatibility of total joint replacements: A review. J Biomed Mater Res A. 2009;90(2):603-618.

18. Heath JC, Freeman MA, Swanson SA. Carcinogenic properties of wear particles from prostheses made in cobalt-chromium alloy. Lancet. 1971;1(7699):564-566.

19. Rae T. The haemolytic action of particulate metals (Cd, $\mathrm{Cr}, \mathrm{Co}, \mathrm{Fe}$, Mo, Ni, Ta, Ti, Zn, Co-Cr alloy). J Pathol. 1978;125(2):81-89.

20. Rae T. The toxicity of metals used in orthopaedic prostheses. An experimental study using cultured human synovial fibroblasts. J Bone Joint Surg Br. 1981;63-B(3):435-440.

21. Albrektsson T, Brånemark PI, Hansson HA, Lindström J. Osseointegrated titanium implants. Requirements for ensuring a long-lasting, direct boneto-implant anchorage in man. Acta Orthop Scand. 1981;52(2):155-170.

22. Rae T. Comparative laboratory studies on the production of soluble and particulate metal by total joint prostheses. Arch Orthop Trauma Surg. 1979;95(1-2):71-79.

23. Depprich R, Zipprich H, Ommerborn M, et al. Osseointegration of zirconia implants compared with titanium: an in vivo study. Head Face Med. 2008;4:30

24. Thomsen P, Larsson C, Ericson LE, Sennerby L, Lausmaa J, Kasemo B. Structure of the interface between rabbit cortical bone and implants of gold, zirconium and titanium. J Mater Sci Mater Med. 1997;8(11): 653-665.
25. Agins HJ, Alcock NW, Bansal M, et al. Metallic wear in failed titaniumalloy total hip replacements. A histological and quantitative analysis. J Bone Joint Surg Am. 1988;70(3):347-356.

26. Tummler HP, Thull R, Schaldach M. The mechanism of repassivation and the concentration of corrosion products shown on TIALV. Proceedings of the World Congress on Medical Physics and Biomedical Engineering, 13th International Conference on Medical and Biological Engineering, and 6th International Conference on Medical Physics; September 5-11, 1982; Hamburg, Germany.

27. Aaron RK, Herr HM, Ciombor DM, et al. Horizons in prosthesis development for the restoration of limb function. J Am Acad Orthop Surg. 2006;14(10 Spec No):S198-S204.

28. Palmquist A, Omar OM, Esposito M, Lausmaa J, Thomsen P. Titanium oral implants: surface characteristics, interface biology and clinical outcome. J R Soc Interface. 2010;7 Suppl 5:S515-S527.

29. Kieswetter K, Schwartz Z, Dean DD, Boyan BD. The role of implant surface characteristics in the healing of bone. Crit Rev Oral Biol Med. 1996;7(4):329-345.

30. Meyer AE, Baier RE, Natiella JR, Meenaghan MA. Investigation of tissue/implant interactions during the first two hours of implantation. J Oral Implantol. 1988;14(3):363-379.

31. Novaes AB, de Souza SL, de Barros RR, Pereira KK, Iezzi G, Piattelli A. Influence of implant surfaces on osseointegration. Braz Dent J. 2010;21(6):471-481.

32. Bobyn JD, Pilliar RM, Cameron HU, Weatherly GC. The optimum pore size for the fixation of porous-surfaced metal implants by the ingrowth of bone. Clin Orthop Relat Res. 1980;(150):263-270.

33. Boyan BD, Lohmann CH, Dean DD, Sylvia VL, Cochran DL, Schwartz Z. Mechanisms involved in osteoblast response to implant surface morphology. Annu Rev Mater Res. 2001;31:357-371.

34. Balshe AA, Assad DA, Eckert SE, Koka S, Weaver AL. A retrospective study of the survival of smooth- and rough-surface dental implants. Int J Oral Maxillofac Implants. 2009;24(6):1113-1118.

35. Pak HS, Yeo IS, Yang JH. A histomorphometric study of dental implants with different surface characteristics. J Adv Prosthodont. 2010;2(4): $142-147$.

36. Ritman EL, Bolander ME, Fitzpatrick LA, Turner RT. Micro-CT imaging of structure-to-function relationship of bone microstructure and associated vascular involvement. Technol Health Care. 1998; 6(5-6):403-412.

37. Clarke B. Normal bone anatomy and physiology. Clin JAm Soc Nephrol. 2008;3 Suppl 3:S131-S139.

38. Sela J, Gross UM, Kohavi D, et al. Primary mineralization at the surfaces of implants. Crit Rev Oral Biol Med. 2000;11(4):423-436.

39. Behari J. Elements of bone biophysics. In: Behari J. Biophysical Bone Behaviour: Principles and Applications. Chichester: John Wiley \& Sons, Ltd; 2009:1-52.

40. Ross FP, Christiano AM. Nothing but skin and bone. J Clin Invest. 2006;116(5):1140-1149.

41. Wolff J. Das Gesetz der Transformation der Knochen, Hirschwald [The Law of Bone Remodeling]. Berlin: Springer-Verlag; 1892. German.

42. Skedros JG, Baucom SL. Mathematical analysis of trabecular 'trajectories' in apparent trajectorial structures: the unfortunate historical emphasis on the human proximal femur. J Theor Biol. 2007;244(1): $15-45$.

43. Frost HM. Mechanical determinants of bone modeling. Metab Bone Dis Rel Res. 1982;4(4):217-229.

44. Currey JD. The mechanical properties of bone. Clin Orthop Relat Res. 1970;(73):210-231.

45. Isaacson BM, Bloebaum RD. Bone bioelectricity: what have we learned in the past 160 years? J Biomed Mater Res A. 2010;95(4): 1270-1279.

46. Buckwalter JA, Glimcher MJ, Cooper RR, Recker R. Bone biology. J Bone Joint Surg. 1995;77:1276-1289.

47. Dimitriou R, Babis GC. Biomaterial osseointegration enhancement with biophysical stimulation. J Musculoskelet Neuronal Interact. 2007;7(3):253-265. 
48. Currey JD. Mechanical properties of bone tissues with greatly differing functions. J Biomech. 1979;12(4):313-319.

49. Currey JD. Effects of differences in mineralization on the mechanical properties of bone. Philos Trans R Soc Lond B Biol Sci. 1984;304(1121): 509-518.

50. Charnley J. Anchorage of the femoral head prosthesis to the shaft of the femur. J Bone Joint Surg Br. 1960;42-B:28-30.

51. Parfitt AM. Misconceptions (2): turnover is always higher in cancellous than in cortical bone. Bone. 2002;30(6):807-809.

52. Bloebaum RD, Bachus KN, Jensen JW, Hofmann AA. Postmortem analysis of consecutively retrieved asymmetric porous-coated tibial components. J Arthroplasty. 1997;12(8):920-929.

53. Eriksson AR, Albrektsson T. Temperature threshold levels for heatinduced bone tissue injury: a vital-microscopic study in the rabbit $J$ Prosthet Dent. 1983;50(1):101-107.

54. Rafel SS. Temperature changes during high-speed drilling on bone. J Oral Surg Anesth Hosp Dent Serv. 1962;20:475-477.

55. Ling RS. Observations on the fixation of implants to the bony skeleton. Clin Orthop Relat Res. 1986;(210):80-96.

56. Abrahamsson I, Linder E, Lang NP. Implant stability in relation to osseointegration: an experimental study in the Labrador dog. Clin Oral Implants Res. 2009;20(3):313-318.

57. Collier JP, Mayor MB, Chae JC, Surprenant VA, Surprenant HP, Dauphinais LA. Macroscopic and microscopic evidence of prosthetic fixation with porous-coated materials. Clin Orthop Relat Res. 1988;(235):173-180.

58. Bobyn JD, Cameron HU, Abdulla D, Pilliar RM, Weatherly GC. Biologic fixation and bone modeling with an unconstrained canine total knee prosthesis. Clin Orthop Relat Res. 1982;(166):301-312.

59. Pilliar RM, Lee JM, Maniatopoulos C. Observations on the effect of movement on bone ingrowth into porous-surfaced implants. Clin Orthop Relat Res. 1986;(208):108-113.

60. Søballe K, Hansen ES, Brockstedt-Rasmussen H, Bünger C. Hydroxyapatite coating converts fibrous tissue to bone around loaded implants. J Bone Joint Surg Br. 1993;75(2):270-278.

61. Cantoni T, Giovanni P. Implant treatment planning in fresh extraction sockets: use of a novel radiographic guide and $\mathrm{CAD} / \mathrm{CAM}$ technology. Quintessence Int. 2009;40(9):773-781.

62. Valente F, Schiroli G, Sbrenna A. Accuracy of computer-aided oral implant surgery: a clinical and radiographic study. Int J Oral Maxillofac Implants. 2009;24(2):234-242.

63. Jeyapalina S, Beck JP, Bachus KN, Bloebaum RD. Cortical bone response to the presence of load-bearing percutaneous osseointegrated prostheses. Anat Rec (Hoboken). 2012;295(9):1437-1445.

64. Bloebaum RD, Willie BM, Mitchell BS, Hofmann AA. Relationship between bone ingrowth, mineral apposition rate, and osteoblast activity. J Biomed Mater Res A. 2007;81(2):505-514.

65. Irish J, Virdi AS, Sena K, McNulty MA, Sumner DR. Implant placement increases bone remodeling transiently in a rat model. $J$ Orthop Res. 2013;31(5):800-806.

66. Frost HM. Perspectives on artificial joint design. J Long Term Eff Med Implants. 1992;2(1):9-35.

67. Frost HM. The Utah paradigm of skeletal physiology: an overview of its insights for bone, cartilage and collagenous tissue organs. $J$ Bone Miner Metab. 2000;18(6):305-316.

68. HM. A determinant of bone architecture. The minimum effective strain. Clin Orthop Relat Res. 1983(175):286-292.

69. Frost HM. The regional acceleratory phenomenon: a review. Henry Ford Hosp Med J. 1983;31(1):3-9.

70. Bourne GH, editor. The Biochemistry and Physiology of Bone. 2nd ed. New York, NY; London: Academic Press; 1972.

71. Rhinelander FW. The normal circulation of bone and its response to surgical intervention. J Biomed Mater Res. 1974;8(1):87-90.

72. Cohen G, Campbell PM, Rossouw PE, Buschang PH. Effects of increased surgical trauma on rates of tooth movement and apical root resorption in foxhound dogs. Orthod Craniofac Res. 2010;13(3): $179-190$
73. Meyer U, Joos U, Mythili J, et al. Ultrastructural characterization of the implant/bone interface of immediately loaded dental implants. Biomaterials. 2004;25(10):1959-1967.

74. Bloebaum RD, Bachus KN, Rubman MH, Dorr LD. Postmortem comparative analysis of titanium and hydroxyapatite porous-coated femoral implants retrieved from the same patient. A case study. J Arthroplasty. 1993;8(2):203-211.

75. Hofmann AA, Bachus KN, Bloebaum RD. Comparative study of human cancellous bone remodeling to titanium and hydroxyapatite-coated implants. J Arthroplasty. 1993;8(2):157-166.

76. Bloebaum RD, Mihalopoulus NL, Jensen JW, Dorr LD. Postmortem analysis of bone growth into porous-coated acetabular components. J Bone Joint Surg Am. 1997;79(7):1013-1022.

77. Bloebaum RD, Bachus KN, Jensen JW, Scott DF, Hofmann AA. Porouscoated metal-backed patellar components in total knee replacement. A postmortem retrieval analysis. J Bone Joint Surg Am. 1998;80(4):518-528.

78. Hagberg K, Brånemark R. Consequences of non-vascular trans-femoral amputation: a survey of quality of life, prosthetic use and problems. Prosthet Orthot Int. 2001;25(3):186-194.

79. Hofmann AA, Bloebaum RD, Bachus KN. Progression of human bone ingrowth into porous-coated implants. Rate of bone ingrowth in humans. Acta Orthop Scand. 1997;68(2):161-166.

80. Slaets E, Naert I, Carmeliet G, Duyck J. Early cortical bone healing around loaded titanium implants: a histological study in the rabbit. Clin Oral Implants Res. 2009;20(2):126-134.

81. Duyck J, Vandamme K, Geris L, et al. The influence of micro-motion on the tissue differentiation around immediately loaded cylindrical turned titanium implants. Arch Oral Biol. 2006;51(1):1-9.

82. Szmukler-Moncler S, Salama H, Reingewirtz Y, Dubruille JH. Timing of loading and effect of micromotion on bone-dental implant interface: review of experimental literature. J Biomed Mater Res. 1998;43(2):192-203.

83. Glauser R, Sennerby L, Meredith N, et al. Resonance frequency analysis of implants subjected to immediate or early functional occlusal loading. Successful vs failing implants. Clin Oral Implants Res. 2004;15(4): 428-434.

84. Meredith N, Alleyne D, Cawley P. Quantitative determination of the stability of the implant-tissue interface using resonance frequency analysis. Clin Oral Implants Res. 1996;7(3):261-267.

85. Röser K, Johansson CB, Donath K, Albrektsson T. A new approach to demonstrate cellular activity in bone formation adjacent to implants. J Biomed Mater Res. 2000;51(2):280-291.

86. Nkenke E, Lehner B, Weinzierl K, et al. Bone contact, growth, and density around immediately loaded implants in the mandible of mini pigs. Clin Oral Implants Res. 2003;14(3):312-321.

87. Slaets E, Carmeliet G, Naert I, Duyck J. Early trabecular bone healing around titanium implants: a histologic study in rabbits. $J$ Periodontol. 2007;78(3):510-517.

88. Piattelli A, Corigliano M, Scarano A, Costigliola G, Paolantonio M. Immediate loading of titanium plasma-sprayed implants: an histologic analysis in monkeys. $J$ Periodontol. 1998;69(3):321-327.

89. Vandamme K, Naert I, Vander Sloten J, Puers R, Duyck J. Effect of implant surface roughness and loading on peri-implant bone formation. J Periodontol. 2008;79(1):150-157.

90. Peñarrocha M, Boronat A, Garcia B. Immediate loading of immediate mandibular implants with a full-arch fixed prosthesis: a preliminary study. J Oral Maxillofac Surg. 2009;67(6):1286-1293.

91. Hofmann AA, Evanich JD, Ferguson RP, Camargo MP. Ten- to 14-year clinical followup of the cementless Natural Knee system. Clin Orthop Relat Res. 2001;(388):85-94.

92. Eswaramoorthy V, Moonot P, Kalairajah Y, Biant LC, Field RE. The Metasul metal-on-metal articulation in primary total hip replacement: clinical and radiological results at ten years. J Bone Joint Surg Br. 2008;90(10):1278-1283.

93. Rocci A, Martignoni M, Gottlow J. Immediate loading of Brånemark System TiUnite and machined-surface implants in the posterior mandible: a randomized open-ended clinical trial. Clin Implant Dent Relat Res. 2003;5 Suppl 1:S57-S63. 
94. Chaushu G, Chaushu S, Tzohar A, Dayan D. Immediate loading of single-tooth implants: immediate versus non-immediate implantation. A clinical report. Int J Oral Maxillofac Implants. 2001;16(2): 267-272.

95. Ericsson I, Nilson H, Lindh T, Nilner K, Randow K. Immediate functional loading of Brånemark single tooth implants. An 18 months' clinical pilot follow-up study. Clin Oral Implants Res. 2000;11(1): 26-33.

96. Calandriello R, Tomatis M, Vallone R, Rangert B, Gottlow J. Immediate occlusal loading of single lower molars using Brånemark System Wide-Platform TiUnite implants: an interim report of a prospective open-ended clinical multicenter study. Clin Implant Dent Relat Res. 2003;5 Suppl 1:S74-S80.

97. Calandriello R, Tomatis M, Rangert B. Immediate functional loading of Brånemark System implants with enhanced initial stability: a prospective 1- to 2-year clinical and radiographic study. Clin Implant Dent Relat Res. 2003;5 Supp1 1:S10-S20.

98. Degidi M, Piattelli A. Immediate functional and non-functional loading of dental implants: a 2- to 60-month follow-up study of 646 titanium implants. J Periodontol. 2003;74(2):225-241.

99. Jeyapalina S, Beck JP, Bloebaum RD, Bachus KN. Progression of Bone Ingrowth and Attachment Strength for Stability of Percutaneous Osseointegrated Prostheses. Clin Orthop Relat Res. Epub 2013 Nov 21.

100. Jeyapalina S, Beck JP, Bachus KN, Williams DL, Bloebaum RD. Efficacy of a porous-structured titanium subdermal barrier for preventing infection in percutaneous osseointegrated prostheses. J Orthop Res. 2012;30(8):1304-1311.

101. Shelton TJ, Beck JP, Bloebaum RD, Bachus KN. Percutaneous osseointegrated prostheses for amputees: Limb compensation in a 12-month ovine model. J Biomech. 2011;44(15):2601-2606.

102. Hansson S. The implant neck: smooth or provided with retention elements. A biomechanical approach. Clin Oral Implants Res. 1999;10(5): 394-405.

103. Hansson S. A conical implant-abutment interface at the level of the marginal bone improves the distribution of stresses in the supporting bone. An axisymmetric finite element analysis. Clin Oral Implants Res. 2003;14(3):286-293.

104. Pospula W, Noor TA, Al Rowaih A. Cementless Zweymüller hip replacement: a short-term follow-up in Al Razi Hospital, Kuwait. Med Princ Pract. 2005;14(4):255-259.

105. Vervest TM, Anderson PG, Van Hout F, Wapstra FH, Louwerse RT, Koetsier JW. Ten to twelve-year results with the Zweymüller cementless total hip prosthesis. J Arthroplasty. 2005;20(3):362-368.

106. Clohisy JC, Calvert G, Tull F, McDonald D, Maloney WJ. Reasons for revision hip surgery: a retrospective review. Clin Orthop Relat Res. 2004;(429):188-192.

107. Fehring TK, Odum S, Griffin WL, Mason JB, Nadaud M. Early failures in total knee arthroplasty. Clin Orthop Relat Res. 2001;(392): 315-318.

108. Del Pozo J, Patel R. Clinical practice. Infection associated with prosthetic joints. N Engl J Med. 2009;361(8):787-794.

109. Craig MR, Poelstra KA, Sherrell JC, Kwon MS, Belzile EL, Brown TE. A novel total knee arthroplasty infection model in rabbits. J Orthop Res. 2005;23(5):1100-1104.

110. Mortazavi SM, Schwartzenberger J, Austin MS, Purtill JJ, Parvizi J. Revision total knee arthroplasty infection: incidence and predictors. Clin Orthop Relat Res. 2010;468(8):2052-2059.

111. Williams DL, Bloebaum RD. Observing the biofilm matrix of Staphylococcus epidermidis ATCC 35984 grown using the CDC biofilm reactor. Microsc Microanal. 2010;16(2):143-152.

112. Williams DL, Woodbury KL, Haymond BS, Parker AE, Bloebaum RD. A modified CDC biofilm reactor to produce mature biofilms on the surface of peek membranes for an in vivo animal model application. Curr Microbiol. 2011;62(6):1657-1663.

113. Fehring TK, Calton TF, Griffin WL. Cementless fixation in 2-stage reimplantation for periprosthetic sepsis. J Arthroplasty. 1999;14(2): $175-181$.
114. Masri BA, Panagiotopoulos KP, Greidanus NV, Garbuz DS, Duncan CP. Cementless two-stage exchange arthroplasty for infection after total hip arthroplasty. J Arthroplasty. 2007;22(1):72-78.

115. Toulson C, Walcott-Sapp S, Hur J, et al. Treatment of infected total hip arthroplasty with a 2-stage reimplantation protocol: update on "our institution's" experience from 1989 to 2003. J Arthroplasty. 2009;24(7):1051-1060.

116. Norowski PA, Bumgardner JD. Biomaterial and antibiotic strategies for peri-implantitis: a review. J Biomed Mater Res B Appl Biomater. 2009;88(2):530-543.

117. Albrektsson T, Isidor F. Consensus report of session IV. In: Lang NP, Karring T, editors. Proceedings of the First European Workshop on Periodontology. London: Quintessence Publishing Co, Inc.; 1994; 365-369.

118. Pontoriero R, Tonelli MP, Carnevale G, Mombelli A, Nyman SR, Lang NP. Experimentally induced peri-implant mucositis. A clinical study in humans. Clin Oral Implants Res. 1994;5(4):254-259.

119. Lindhe J, Meyle J; Group D of European Workshop on Periodontology. Peri-implant diseases: Consensus Report of the Sixth European Workshop on Periodontology. J Clin Periodontol. 2008;35(Suppl 8): S282-S285.

120. Pye AD, Lockhart DEA, Dawson MP, Murray CA, Smith AJ. A review of dental implants and infection. J Hosp Infect. 2009;72(2):104-110.

121. Klinge B, Hultin M, Berglundh T. Peri-implantitis. Dent Clin North Am. 2005;49(3):661-676.

122. Roos-Jansåker AM, Renvert S, Egelberg J. Treatment of peri-implant infections: a literature review. J Clin Periodontol. 2003;30(6): 467-485.

123. Tanner A, Maiden MF, Lee K, Shulman LB, Weber HP. Dental implant infections. Clin Infect Dis. 1997;25 Suppl 2:S213-S217.

124. Karoussis IK, Salvi GE, Heitz-Mayfield LJ, Brägger U, Hämmerle CH, Lang NP. Long-term implant prognosis in patients with and without a history of chronic periodontitis: a 10-year prospective cohort study of the ITI Dental Implant System. Clin Oral Implants Res. 2003;14(3): 329-339.

125. Klinge B, Gustafsson A, Berglundh T. A systematic review of the effect of anti-infective therapy in the treatment of peri-implantitis. J Clin Periodontol. 2002;29 Suppl 3:S213-S225; discussion 232-233.

126. Leonhardt A, Dahlén G, Renvert S. Five-year clinical, microbiological, and radiological outcome following treatment of peri-implantitis in man. J Periodontol. 2003;74(10):1415-1422.

127. Renvert S, Roos-Jansåker AM, Claffey N. Non-surgical treatment of peri-implant mucositis and peri-implantitis: a literature review. J Clin Periodontol. 2008;35(Suppl 8):S305-S315.

128. Claffey N, Clarke E, Polyzois I, Renvert S. Surgical treatment of periimplantitis. J Clin Periodontol. 2008;35(Suppl 8):S316-S332.

129. Albrektsson T, Brånemark PI, Jacobsson M, Tjellström A. Present clinical applications of osseointegrated percutaneous implants. Plast Reconstr Surg. 1987;79(5):721-731.

130. Hagberg K, Brånemark R. One hundred patients treated with osseointegrated transfemoral amputation prostheses - rehabilitation perspective. J Rehabil Res Dev. 2009;46(3):331-344.

131. Kang NV, Pendegrass C, Marks L, Blunn G. Osseocutaneous integration of an intraosseous transcutaneous amputation prosthesis implant used for reconstruction of a transhumeral amputee: case report. J Hand Surg Am. 2010;35(7):1130-1134.

132. Aschoff HH, Clausen A, Hoffmeister T. [The endo-exo femur prosthesis - a new concept of bone-guided, prosthetic rehabilitation following above-knee amputation]. Z Orthop Unfall. 2009;147(5): 610-615. German.

133. Tillander J, Hagberg K, Hagberg L, Brånemark R. Osseointegrated titanium implants for limb prostheses attachments: infectious complications. Clin Orthop Relat Res. 2010;468(10):2781-2788.

134. Gunterberg B, Brånemark PI, Brånemark R, Bergh P, Rydevik B. Osseointegrated prosthesis in lower limb amputation. The development of a new concept. In: Program and abstracts of the IXth World Congress of the International Society for Prosthetics and Orthotics; June 28-July 3, 1998; Amsterdam, The Netherlands. 
135. Aschoff HH, Kennon RE, Keggi JM, Rubin LE. Transcutaneous, distal femoral, intramedullary attachment for above-the-knee prostheses: an endo-exo device. J Bone Joint Surg Am. 2010;92 Suppl 2:S180-S186.

136. Juhnke D-L. Über die Endo-Exo-Femurprothese: Erarbeitung von Konzepten für die Qualitätssicherung knochengeführter Oberschenkelprothesen durch ganganalytische Bestimmungen und Auswertung von Druckverläufen unter dem Fuß. Munchen, Germany: Medizinische Fakultät, Ludwig-Maximilians-Universitat München; 2010.

137. Sullivan J, Uden M, Robinson KP, Sooriakumaran S. Rehabilitation of the trans-femoral amputee with an osseointegrated prosthesis: the United Kingdom experience. Prosthet Orthot Int. 2003;27(2): 114-120.

138. Bragdon, CR, Nebergall AK, Antonellis A, Kärrkolm J, Brånemark R, Örjan B, Malchau H. RSA evaluation of an implant system for above the knee amputee patients. Oral presentation at the 4th International Conference on Advances in Orthopaedic Osseointegration; February 10, 2012; San Francisco, CA.

139. Hacking SA, Bobyn JD, Toh K, Tanzer M, Krygier JJ. Fibrous tissue ingrowth and attachment to porous tantalum. J Biomed Mater Res. 2000;52(4):631-638.

140. Brånemark PI, Albrektsson T. Titanium implants permanently penetrating human skin. Scand J Plast Reconstr Surg. 1982;16(1): 17-21.

141. Vandamme K, Naert I, Geris L, Sloten JV, Puers R, Duyck J. Histodynamics of bone tissue formation around immediately loaded cylindrical implants in the rabbit. Clin Oral Implants Res. 2007;18(4): 471-480.

142. Uhthoff HK, Germain JP. The reversal of tissue differentiation around screws. Clin Orthop Relat Res. 1977;(123):248-252.

143. Albrektsson T, Johansson C. Osteoinduction, osteoconduction and osseointegration. Eur Spine J. 2001;10 Supp1 2:S96-S101.

144. Morinaga K, Kido H, Sato A, Watazu A, Matsuura M. Chronological changes in the ultrastructure of titanium-bone interfaces: analysis by light microscopy, transmission electron microscopy, and micro-computed tomography. Clin Implant Dent Relat Res. 2009;11(1):59-68.

145. Stoppie N, van der Waerden JP, Jansen JA, Duyck J, Wevers M, Naert IE. Validation of microfocus computed tomography in the evaluation of bone implant specimens. Clin Implant Dent Relat Res. 2005;7(2): 87-94.
146. Huja SS, Roberts WE. Mechanism of osseointegration: characterization of supporting bone with indentation testing and backscattered imaging. Semin Orthod. 2004;10(2):162-173.

147. Tuan HS, Hutmacher DW. Application of micro CT and computation modeling in bone tissue engineering. Comput Aided Des. 2005;37(11): 1151-1161.

148. Yip G, Schneider P, Roberts EW. Micro-computed tomography: high resolution imaging of bone and implants in three dimensions. Semin Orthod. 2004;10(2):174-187.

149. Huang HM, Chiu CL, Yeh CY, Lee SY. Factors influencing the resonance frequency of dental implants. J Oral Maxillofac Surg. 2003;61(10):1184-1188

150. Pattijn V, Jaecques SV, De Smet E, et al. Resonance frequency analysis of implants in the guinea pig model: influence of boundary conditions and orientation of the transducer. Med Eng Phys. 2007;29(2) 182-190.

151. Pattijn V, Van Lierde C, Van der Perre G, Naert I, Vander Sloten J. The resonance frequencies and mode shapes of dental implants: Rigid body behaviour versus bending behaviour. A numerical approach. J Biomech. 2006;39(5):939-947.

152. Schliephake H, Sewing A, ArefA. Resonance frequency measurements of implant stability in the dog mandible: experimental comparison with histomorphometric data. Int J Oral Maxillofac Surg. 2006;35(10): 941-946

153. Veltri M, Balleri B, Goracci C, Giorgetti R, Balleri P, Ferrari M. Soft bone primary stability of 3 different miniscrews for orthodontic anchorage: a resonance frequency investigation. Am J Orthod Dentofacial Orthop. 2009;135(5):642-648.

154. Isaacson BM, Vance RE, Chou TG, Bloebaum RD, Bachus KN, Webster JB. Effectiveness of resonance frequency in predicting orthopedic implant strength and stability in an in vitro osseointegration model. J Rehabil Res Dev. 2009;46(9):1109-1120.

155. Bloebaum RD, Rubman MH, Hofmann AA. Bone ingrowth into porous-coated tibial components implanted with autograft bone chips. Analysis of ten consecutively retrieved implants. J Arthroplasty. 1992;7(4):483-493.

156. Bloebaum RD, Rhodes DM, Rubman MH, Hofmann AA. Bilateral tibial components of different cementless designs and materials. Microradiographic, backscattered imaging, and histologic analysis Clin Orthop Relat Res. 1991179-1991187.
Orthopedic Research and Reviews

\section{Publish your work in this journal}

Orthopedic Research and Reviews is an international, peer-reviewed, open access journal focusing on the patho-physiology of the musculoskeletal system, trauma, surgery and other corrective interventions to restore mobility and function. Advances in new technologies, materials, techniques and pharmacological agents are particularly welcome. The journal welcomes

\section{Dovepress}

original research, clinical studies, reviews \& evaluations, expert opinion and commentary, case reports and extended reports. The manuscript management system is completely online and includes a very quick and fair peer-review system, which is all easy to use. Visit http://www.dovepress. com/testimonials.php to read real quotes from published authors. 